\title{
CULTURAL HERITAGE PROTECTION SYSTEM IN JAPAN: CURRENT ISSUES AND PROSPECTS FOR THE FUTURE
}

Japan has been modernizing for the past 150 years, wiping out the old for the sake of socio-economic progress. Since the end of World War II (WWII) in particular, Japan's new constitution renounced war and Japan placed a strong focus on economic development. In many cases, the protection of cultural heritage was marginalized.

However, in recent years, Japan's society and economy have matured, and the national demand for a better quality of life has increased. Demand for non-material satisfaction has led to growing concern about social cohesion, local identity, and culture. On the other hand, due to structural changes in the economy and production, industries have also increased attention to the importance of utilizing culture for the creation of economic value. Thus, cultural heritage has been integrated into local communities and has gradually come to be considered an important component of a high-quality lifestyle as well as a precious resource for regional development through cultural tourism and the creation of high value-added products. Accordingly, the cultural heritage protection system has evolved to meet these socio-economic changes.

The main purpose of this paper is to overview the major achievements of cultural heritage protection in general, which comprises the core of Japanese cultural policy. Also the underlying socio-economic changes will be addressed. Then, current issues and prospects for the future will be considered.

This paper is largely based on GRIPS Discussion Paper 14-10, written by the author, and was revised for this journal with the support of JSPS KAKENHI Grant Number 26380292. Except as otherwise cited, data used in this paper are based on Agency for Cultural Affairs (2001, 2016).

\section{Brief history of cultural heritage protection in Japan ${ }^{1}$}

1) Evolution of the heritage protection system in modern Japan (until WWII)

Heritage has been protected in Japan for over a thousand years. There are several terms referring to the items protected in Japan. The present Law for the Protection

1 This section is based on original government documents, Cultural properties preservation policy (in Japanese), eds. T. Kawamura et al., Tokai University Press, Tokyo 2002; E. Kakiuchi, Protection 
of Cultural Properties refers to them as Cultural Properties, although they were referred to as antiques, national treasures, and specially protected buildings in the past. In this paper, when referring to items specifically protected under the legal system, the words used in the corresponding laws are cited; the word 'heritage' is used when referring to items protected in general.

Shoso-in, the first museum in Japan, dates back to the $8^{\text {th }}$ century; it is the Imperial storehouse in Todai-ji temple and a designated national treasure (included in the World Heritage List), which contains many artifacts and books from the Nara era ( $8^{\text {th }}$ century). It is now under the supervision of the Imperial Household Agency. Shoso-in is well known as a building with an ancient architectural style utilizing intercrossed triangle logs.

Many precious artifacts, buildings, and other valuable items throughout Japan have been protected by stakeholders for a variety of purposes: religious, educational, and social. The modern Meiji government started to protect heritage for the sake of the entire nation as a part of public policy. Modern Japan started with the 1868 Meiji restoration, when Japan ended several hundred years of national isolation. In order to avoid colonization by western powers, the Meiji government eagerly promoted civilization and enlightenment (which was regarded as synomyous with westernization) to help Japan emerge as a civilized military power. Introducing western arts and culture was one of the tools used to attain this national goal, and people lost their interest in pre-modern values in general.

The Meiji restoration also brought about the decline of the previous ruling classes: the families of feudal lords, including the Tokugawas, who had played a major role in the collection and protection of many valuable items. At the same time, the Meiji government introduced an ordinance in 1868 to officially categorize Shinto and Buddhism. Shinto shrines were declared to be the nation's official houses of worship in 1871. This policy led to an anti-Buddhist movement and the neglect of Buddhismrelated items. Also land owned by Buddhist temples and Shinto shrines, which had been granted in the Edo period (c. 1600-1868), was seized by the government under the Confiscation Law (Agechi-rei) in 1871 and 1875. Buddhist temples lost their followers, supporters, and financial base, which led to loss of religious heritage. Collections of the former ruling classes and temples were scattered and lost. Also national land development and rapid industrialization brought about loss of historic sites, places of scenic beauty, and monuments throughout the nation.

The following section introduces a series of important measures taken by the government for heritage protection.

of Cultural Properties and Sustainable Development in Japan, 2003 DVD produced in cooperation with the World Bank Institute, http://www3.grips.ac.jp/ culturalpolicy/rsc/aud/aud_kakiuchi_English.asx; A. Uchida, Commentary on the Law for the Protection of Cultural Properties (in Japanese), "Jichi kenkyu" 1983, 58, 4, pp. 42-66. 
a) The first effort: the Proclamation for the Protection of Antiques and Old Properties (1871-1897)

The Meiji government started heritage protection efforts in 1871 with the enactment of the Proclamation for the Protection of Antiques and Old Properties. This proclamation was the first law, aimed at conducting surveys, registering and collecting antiques in thirty-one specific categories which included almost all the present categories of cultural properties in Japan, except immovable ones. More than 200,000 items were listed under this proclamation at that time. This proclamation was revoked in 1897 and replaced by the Ancient Shrines and Temples Preservation Law.

The survey conducted under the 1871 proclamation revealed the serious conditions of precious belongings of temples, in Nara and Kyoto in particular, and the establishment of national museums was recommended. The Nara National $\mathrm{Mu}-$ seum was established in 1895, and in 1897 the Kyoto National Museum was established. Also many registered cultural properties were exhibited in the first National Exhibition in the Sacred Hall at Yushima in 1872, and a part of the collection of this exhibit provided the foundation for the first national museum (the present Tokyo National Museum).

b) Provision of funds to temples and shrines and the prototype

of the present heritage protection system in Japan:

the Ancient Shrines and Temples Preservation Law (1897-1929)

During 1880-1894, the Meiji government provided funds to declining temples and shrines, encouraged to use these funds for repair of the buildings. However, surveys under the proclamation mentioned above and government funding were insufficient to protect antiques and historic buildings. After the victory in the war with China, nationalism and awareness of the importance of heritage were fostered and the government strengthened protection of cultural and historical heritage. This led to the enactment of a more comprehensive Law: the Ancient Shrines and Temples Preservation Law.

Under this law, the government could provide funds for repairing buildings of temples and shrines in response to their requests, designate the items to be protected as National Treasures and Specially Protected Buildings regardless of whether or not they belonged to temples, and order these items to be exhibited in national museums. The grants have been provided for those items when they were exhibited. The disposal or sale of National Treasures was prohibited, and penalties for violations were prescribed. This Law was regarded as a prototype of the subsequent system of heritage protection in Japan as it combined national designation and restrictions with provisions for financial support. 
c) The Law for the Preservation of Historic Sites, Places

of Scenic Beauty and Natural Monuments (1919-1950)

The Law for the Preservation of Historic Sites, Places of Scenic Beauty and Natural Monuments aimed at protecting historic sites and monuments that were at risk of deterioration due to modernization and fell outside the scope of the law discussed above.

Under this law, the government could have designated Historic Sites, Places of Scenic Beauty, and Monuments. Once they were designated, financial support was provided by the government, while any actions which might affect their condition were the subject to permission issued by the government, and, if necessary the government could prohibit or limit those actions. In addition, the government could order the establishment of any facilities necessary to protect them. The management of those historic sites and others could be tasked to local governments. However, it should be noted that some of the designations were made for political reasons, such as places visited by the emperors. They were delisted later after WWII unless their academic values were recognized.

d) The National Treasures Preservation Law (1929-1950)

The Ancient Shrines and Temples Preservation Law was superseded by the National Treasures Preservation Law in 1929, but designations under the former Law continued to be in effect under the new Law. The scope of national heritage protection was expanded beyond temples and shrines to publicly owned castles, possessions of former feudal lords, and other valuables.

Under this Law, the government could have designated any buildings and treasures of historic significance or recognized beauty as National Treasures. Many measures to protect the value of National Treasures were authorized by this Law; sale, disposal, or changes of status were prohibited unless permitted by the government. The export of designated National Treasures was prohibited for the first time. This Law also required that changes of ownership and loss or damage should be reported to the government, while the repair of National Treasures was financially supported. In return, the owners of National Treasures were required to exhibit their possessions at national museums (for less than one year), with compensation from the government.

e) The Law Concerning the Preservation of Important Objects of Arts (1933-1950)

Due to economic depression and devaluation of the yen at the beginning of the $20^{\text {th }}$ century, many antiques which had not been designated as National Treasures were 
exported. The newly enacted Law Concerning the Preservation of Important Objects of Arts aimed at stopping these exports temporarily until these antiques could be designated as National Treasures. The owners of Important Objects of Art were required to ask permission from the government before exporting them, and the government was required to decide within one year either to designate them as National Treasures or give permission for export. However, this temporary measure gradually changed to accreditation of the artistic importance of Important Objects of Art ranked immediately below designated National Treasures.

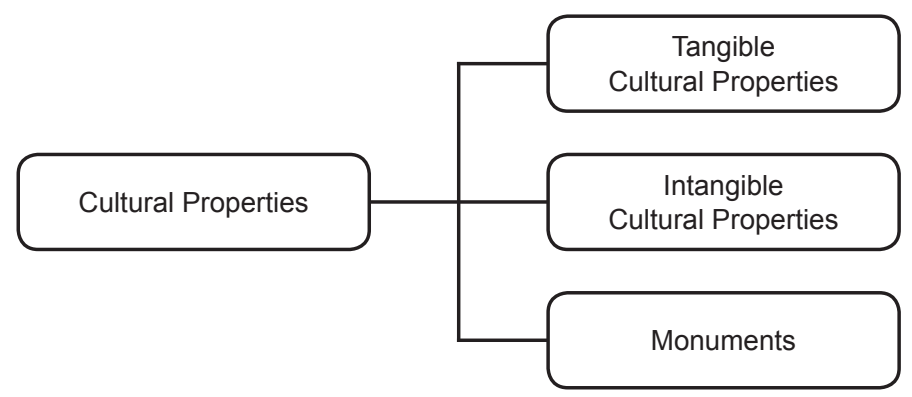

Fig. 1. Schematic diagram of cultural properties (1950)

Source: Prepared by the author based on the Law for the Protection of Cultural Properties enacted in 1950.

The above Law was abolished when the Law for the Protection of Cultural Properties was enacted in 1950. Some Important Objects of Art were designated as Important Cultural Properties under the new Law, but the pre-1950 designation of other Important Objects of Art, which were not designated as Important Cultural Properties under the Law for the protection of Cultural Properties mentioned in 2), still remains in effect even today, even though this designation was originally intended only as a temporary measure.

2) Post-war system of heritage protection:

the Law for the Protection of Cultural Properties

a) The enactment of the Law for the Protection of Cultural Properties

During and after WWII, efforts regarding heritage protection stopped almost completely. Immediately after the end of WWII, heritage protection efforts gradually resumed. However, these efforts faced great difficulty because of hyper-inflation, heavy taxes, and the psychological damage from Japan's defeat, as well as a public loss of interest in tradition. 
In 1949, a fire at Horyu-ji temple, the oldest wooden structure in Japan (now included in the World Heritage List), destroyed outstanding wall paintings in its Buddha Hall. This accident induced a strong national sentiment for cultural protection, which led to the enactment of the Law for the Protection of Cultural Properties in 1950 (hereafter referred to as LPCP).

Under LPCP, the national government and local governments are requested to take necessary measures for protecting heritage. At the same time, owners and custodians are requested to make efforts to protect heritage, while the general populace is requested to cooperate with the government. It should be noted that unlike the pre-war era, when only the national government could designate cultural heritage, local governments can also designate their own cultural properties. This contributes to democratization in the designation of cultural properties. However, due to limitations on financial resources, the national government plays the major role in heritage conservation, albeit with increasing contributions by other stakeholders.

LPCP integrates pre-war tangible heritage - artifacts, buildings and historic sites, and monuments - with the new concept of intangible cultural properties (Fig. 1). Cultural Properties are defined by LPCP as cultural productions of historic, artistic, and/or academic value for Japan. They are essential for understanding the history and culture of Japan, and form the foundation for cultural progress in Japan and the world (articles 1 and 2 of LPCP).

Under LPCP, the national government designates Important Cultural Properties and National Treasures of high historic, artistic and/or scientific value, and it imposes restrictions on repairs, export, and alterations to existing appearance. The government also undertakes a range of measures for protection which includes both preservation and utilization.

In the following sections, the details of each category and of the protection measures, respectively, are discussed.

\section{b) Cultural Properties}

At the time of its enactment in 1950, three categories were introduced as Cultural Properties to be protected by LPCP.

The first category, Tangible Cultural Properties, is composed of two elements: works of fine arts (movable cultural properties) such as crafts, paintings, sculptures and others, and buildings and structures (immovable cultural properties).

The second category of Cultural Properties is Monuments, including Historic Sites such as shell mounds, ancient burial mounds, and ancient capital ruins, Places of Scenic Beauty such as gardens, gorges, and mountains, and Natural Monuments such as fauna, flora, and geological minerals. In addition, the new concept of Intangible Cultural Properties such as stage arts and music was introduced. 
Some differences are apparent between the concept of Cultural Properties as described by LPCP, which was enacted in 1950, and the concept of cultural heritage of the "World Heritage Convention" (adopted at the UNESCO meeting in 1972, and ratified by Japan in 1992). Cultural Properties is a comprehensive and broad concept including not only tangible heritage (both immovable and movable) but also intangible heritage such as theatrical performing arts, as well as natural heritage, including species of animals and plants, geological minerals, gardens, and mountains. It should be noted that in order to protect intangible cultural properties, LPCP includes protection measures for so-called national living treasures who embody technical artistry. However, since the "Convention for the Safeguarding of the Intangible Cultural Heritage" (adopted at the UNESCO meeting in 2003, and ratified by Japan in 2004), the international approach of integrating tangible and intangible heritage together has been ongoing, which is diminishing the differences between heritage and cultural properties.

\section{c) Measures for protection}

LPCP stipulates that cultural properties are assets shared by the entire nation, and for this purpose, it defines protection as a combination of preservation of the existing state of cultural properties and their utilization for cultural promotion as a whole.

The national government designates cultural properties of national importance, while those having regional interest and value (excluding national classifications) can be designated by relevant local governments. It should be noted that LPCP stipulates that designation should be made with reasonable respect for the property rights of private owners of cultural properties. Thus, in actual implementation, governments seek the agreement of the private owners.

It is the responsibility of the owners, custodial bodies, and/or administrative organizations to protect the existing condition of the designated cultural properties. LPCP requires the owners to carry out regular repairs and actions for disaster prevention, the costs of which are partly subsidized by the government. Additionally, some taxes on cultural properties such as the fixed asset tax (property tax) are exempted. The owners must report the transfer of ownership, as well as any loss, destruction, or damage, so that the government can be aware of the condition of all designated cultural properties. Any alteration of the existing state of designated cultural properties as well as export requires the permission of the Commissioner for Cultural Affairs. The general public is requested to cooperate with all actions for the protection of cultural properties.

In the following sections, the evolution of LPCP in Japan will be illustrated, focusing on socio-economic change and emerging social demands for heritage protection, particularly on local development. 


\section{3) Evolution of LPCP}

a) Confrontation with development (1960s-1970s)

In the 1960s and 1970s, when Japan experienced rapid economic growth: the National Income Doubling Plan and the Comprehensive National Development Plan were put into effect in 1960 and 1962, respectively; in 1964, Shinkansen (bullet train) service was inaugurated, and the Olympic Games were held in Tokyo. However, this rapid growth led to serious social problems such as disorderly development, excessive centralization, and depopulation of rural areas. At the same time, rapid urbanization and economic development destroyed historic towns, and the environment surrounding traditional buildings deteriorated. Due to the drastic changes in industrial structure and the modernization of people's lifestyle, some performing folk arts, traditional customs, and buried cultural properties were lost.

In 1965, triggered by the building of houses in the backyard of the famous Tsurugaoka Hachimangu Shrine (which is now registered on the UNESCO Tentative List of the World Heritage Convention), in the heart of Kamakura, a city near Tokyo, a civic movement for the protection not only of historic buildings but also of historic landscapes gained public support. This led to the enactment of the Law for Preservation of Ancient Capitals (hereafter referred to as LPAC) in 1966.

However, the LPAC applies only to ancient national capitals such as Kamakura, Kyoto, Nara, and several other cities. As for cities not covered by the LPAC, in 1968, the city of Kanazawa was the first to enact an ordinance aiming to conserve the traditional environment of the city so it could be passed on to succeeding generations. This ordinance was implemented through a zoning system for the protection of traditional landscapes through subsidies, which became a prototype for heritage conservation by other local governments. Many other local governments started to enact regulations to protect historic landscapes, seeking an environment conducive to a high standard of living and re-evaluating historic landscapes which were lost due to rapid development.

These developments led to the revision of LPCP by the national government in 1975. Several important changes and revisions were made (conservation Techniques for Cultural Properties and Folk Cultural Properties, including Folk Performing Arts, were introduced), protection of Buried Cultural Properties was strengthened, and a new category of cultural properties, Groups of Traditional Buildings, was introduced.

In order to protect Groups of Traditional Buildings, Preservation Districts for Groups of Traditional Buildings are designated by local governments to be protected by formulating protection master plans to control alteration of the existing state based on ordinances and regulations. In these districts, it became possible to protect not only specifically designated buildings, but also groups of historic buildings where 
people still live. The exteriors of these buildings are the main objects to be protected, unlike Important Cultural Properties for which both the exterior and the interior are strictly preserved. It is the responsibility of local governments to designate these districts based on a consensus of the residents, while the national government selects districts with high value from among the locally designated ones and covers part of the cost of protection. Thus, regional development and daily activities of local residents become compatible with the protection of cultural properties.

b) Co-existence with development (1980s-1990s)

In the 1980s and 1990s, culture and region increasingly became key words for all aspects of life in Japan. As shown in Fig. 2, people have increasingly considered non-material satisfaction to be more important than material satisfaction since the 1980s. They also gradually recognized cultural properties as an important component of social cohesion and local identity, as well as a valuable resource for development. Many local governments took action to preserve the historic atmosphere of each town and utilize local historic sites.

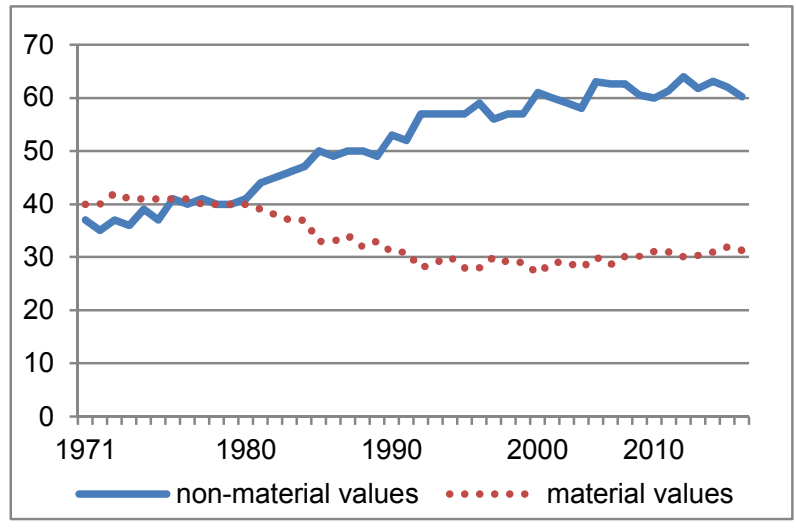

Fig. 2. National survey on values (\%)

Source: Cabinet Office, Government of Japan, National Survey on Values, each year. http://survey.gov-online.go.jp/h28/h28-life/2-2.html (accessed: 19.12.2016).

In 1992, Japan ratified the UNESCO World Heritage Convention, and heritage sites in Japan have been added to the World Heritage List over the ensuing years. Various measures have been taken by governments to protect not only the heritage sites but also surrounding buffer zones. These developments have also contributed to raising awareness of the importance of cultural properties and surrounding environments as well. 
However, despite the expansion and diversification of cultural properties protection, many buildings and structures that were not designated under LPCP have been lost, although had significant cultural value. Due to land development, urbanization, and changes in lifestyle, landmark buildings and structures of the modern period with different styles were particularly in danger of demolition. In 1996, LPCP was revised and a new measure for protection of cultural properties was introduced: registration of traditional buildings. This new measure complements the existing designation system, providing moderate protection measures such as notification, guidance, suggestions and advice. Once registered, unlike Important Cultural Properties, owners of the traditional buildings are expected to protect the main features of the exterior of the buildings, but they have more flexibility to renovate them. This registration system was later expanded to such categories as Monuments and Folk Cultural Properties in 2004.

c) Closer linkage with development (2001-present)

At the dawn of the $21^{\text {st }}$ century, reflecting a broad social consensus on the importance of culture, the Fundamental Law for the Promotion of Culture and Arts was enacted in Japan in 2001. This law incorporates a broad and inclusive definition of culture, and also makes provisions for the support of cultural activities by local governments, non-profit organizations (NPOs), companies, and citizens. After the Great Kobe Earthquake in 1995, the victims were greatly helped by NPOs and the importance of NPOs was widely recognized, which led to the enactment of the Law to Promote Specified Nonprofit Activities in 1996. Until 2016, 51,261 Approved Specified Nonprofit Corporations based on this Law were operating in Japan, among which more than 35\% were operating in the field of science, art, culture and sports ${ }^{2}$. Thus, not only government, but also various other entities are actively involved in culture, including the protection of cultural properties.

On the other hand, from an urban planning perspective, reflecting the social demand for more pleasant life in a community and tourism promotion, the Landscape Act was enacted in 2004, aiming to create pleasant and beautiful scenery in cities and villages. This is the first law in Japan which refers to the importance of the beanty of cities and villages, and stipulates that the national government is responsible for extending financial support through zoning, and, if necessary, restriction of the private rights of landowners. Citizens and NPOs are encouraged to be actively involved in the implementation of this law. LPCP was revised and a new category of cultural properties, Cultural Landscape, was introduced in the same year, aiming to protect significant cultural landscape sites such as rice terraces and coppice

2 Cabinet Office, Government of Japan, National Survey on NPOs, https://www.npo-homepage.go.jp/about/toukei-info/ninshou-bunyabetsu (accessed: 19.12.2016). 
woodlands. As in the case of the Preservation Districts for Groups of Traditional Buildings, local governments designate a certain area and its cultural landscape for protection. The national government selects high value areas as Important Cultural Landscapes from among the locally designated ones, and provides support.

In 2006, the Tourism National Promotion Basic Law was fully revised to strengthen strategic measures to attract tourists from all over the world. The number of inbound travelers to Japan is much smaller than that of outbound Japanese travelers. In order to reduce this imbalance, the government launched the Visit Japan Campaign and established the Japan Tourism Agency within the Ministry of Land, Infrastructure, Transport and Tourism. Recognizing the importance of tourism as a growth industry, this Law supports utilization of local cultural assets including historic sites, places of scenic beauty, monuments, landscapes, hot springs and traditional industries. In this law, culture is clearly stated as one of the important components of tourism.

In 2008, the Act on the Maintenance and Improvement of Historic Landscape in a Community was enacted under the joint authority of the sections responsible for cultural promotion, tourism, and agriculture. This act stipulates various measures to support conservation of historic atmosphere through extending financial support and tax incentives. The relationship between protection of cultural properties and tourism promotion is discussed in detail below.

\section{Assessing achievements over the past 50 years}

We now consider the achievement of LPCP and the implications of several other legal measures concerning protection of cultural properties.

\section{1) Expansion of the concept of Cultural Properties}

In 1950, when LPCP was enacted, only three categories of cultural properties were listed (Fig. 3). In the 60 years since then, under LPCP, six categories of cultural properties as well as two other categories are now listed as eligible for protection.

Folklore Materials was designated as one independent category of Cultural Properties in 1954 and the category was renamed Folk Cultural Properties in 1975. Folk Cultural Properties are composed of Tangible Folk Cultural Properties: clothing, instruments, and dwellings, and Intangible Folk Properties: manners and customs, folk performing arts, and folk techniques concerning food, clothing, housing, occupation, religious faith, and events. 


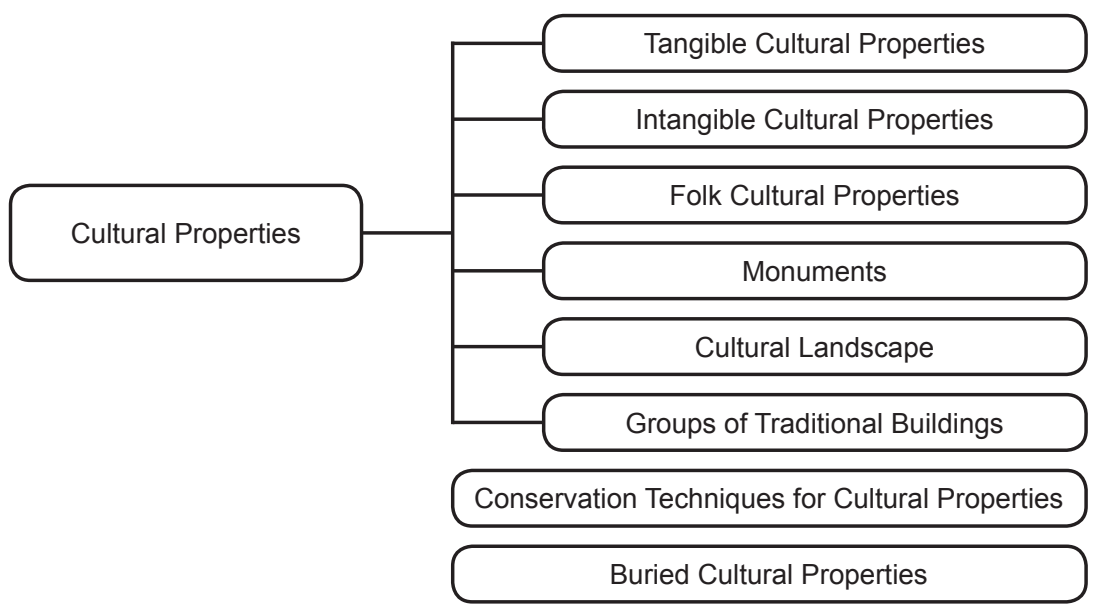

Fig. 3. Schematic Diagram of Cultural Properties (2016)

Source: Prepared by the author based on the present LPCP latest revised in 2014.

Groups of Traditional Buildings such as post towns, castle towns, farming and fishing villages have been protected since 1975, and Cultural Landscapes such as terraced rice fields, rural landscapes, and waterways have been protected since 2004 .

In addition, Conservation Techniques for Cultural Properties have been designated and protected since 1975, and Buried Cultural Properties, which are direct evidence of our predecessors' lives and valuable common historical properties, have been protected since 1954.

\section{2) Diversified protection measures}

LPCP requires the national government (specifically, the Minister of Education, Culture, Sports, Science and Technology) to designate, select, or register the most important properties with high nationwide values. The classification and selection criteria are publicly announced.

The most basic and strongest form of classification is designation, which imposes both a strong restriction on owners not to alter their cultural properties and provides strong financial support. As for Intangible Cultural Properties, the national government designates especially significant performing arts or craft techniques and at the same time recognizes individuals or groups of individuals who are masters of the techniques concerned. These recognized individuals are commonly called National Living Treasures, and the government extends subsidies for training successors or public performances and exhibitions. Among the designated Important Cultural Properties, especially valuable ones are designated as National Treasures or Special Monuments. 
More moderate forms of classification such as selection and registration were introduced in 1975 and 1996, respectively, which diversified the range of possible protection measures. Both registration and selection allow owners to alter cultural properties under certain conditions, while public support is also moderate compared with the case of designation.

On the other hand, in order to preserve valuable Buried Cultural Properties, LPCP restricts excavation and construction on these sites. Those who conduct excavation for any purpose, whether research or construction, are required to notify the Commissioner for Cultural Affairs concerning their plan of excavation. In case it is impossible to preserve the present state of ruins, excavation and documentation of the results must be conducted by developers at their own expense. In actual implementation, the work related to protection of buried cultural properties occupies a large part of the cultural properties protection efforts of local governments.

For heritage protection, museums and theaters contributed greatly to collection, exhibition, research and training. National museums host many Important Cultural Properties. The national theater founded in 1966 played a great role in training performers in the field of traditional theatrical performances; more than $30 \%$ of Kabuki performers and more than half of Bunraku performers are graduates of the training schools affiliated with the national theater ${ }^{3}$.

3) Increase in the number of protected cultural properties

As shown in Table 1, the number of nationally classified Cultural Properties has increased almost twofold in the past six decades. Until 2016, 13,110 designations had been made: 10,654 Works of Fine Arts and Crafts (including 878 National Treasures) and 2,456 buildings and other structures (including 223 National Treasures).

On the other hand, the recognition of individuals and groups as the holders of Important Intangible Cultural Properties reached 77 and 27, respectively. Designated Monuments have increased, amounting to 3,179 sites; among which roughly half are Historic Sites. There are 61 Special Historic Sites, 36 Special Places of Scenic Beauty, and 75 Special Natural Monuments.

The designation of new categories of Cultural Properties has also increased. Until 2016, there were 217 Important Tangible Folk Cultural Properties, and 296 Important Intangible Folk Cultural Properties designated as significant folk cultural properties which are indispensable to understanding peoples' lives.

3 http://www.ntj.jac.go.jp/training/outline/group01.html (accessed: 12.19.2016); http://www. ntj.jac.go.jp/training/outline/group08.html (accessed: 12.19.2016). 


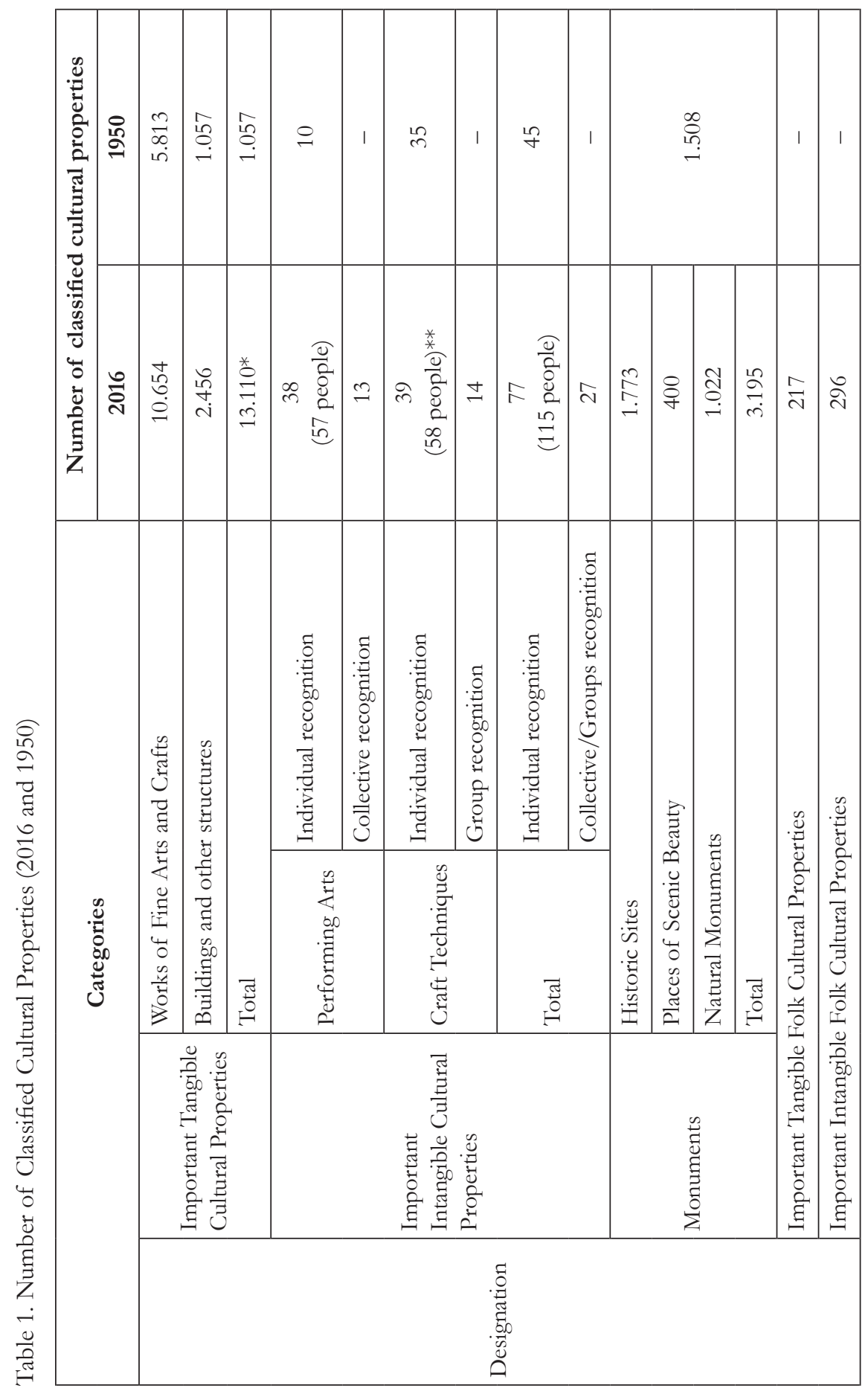




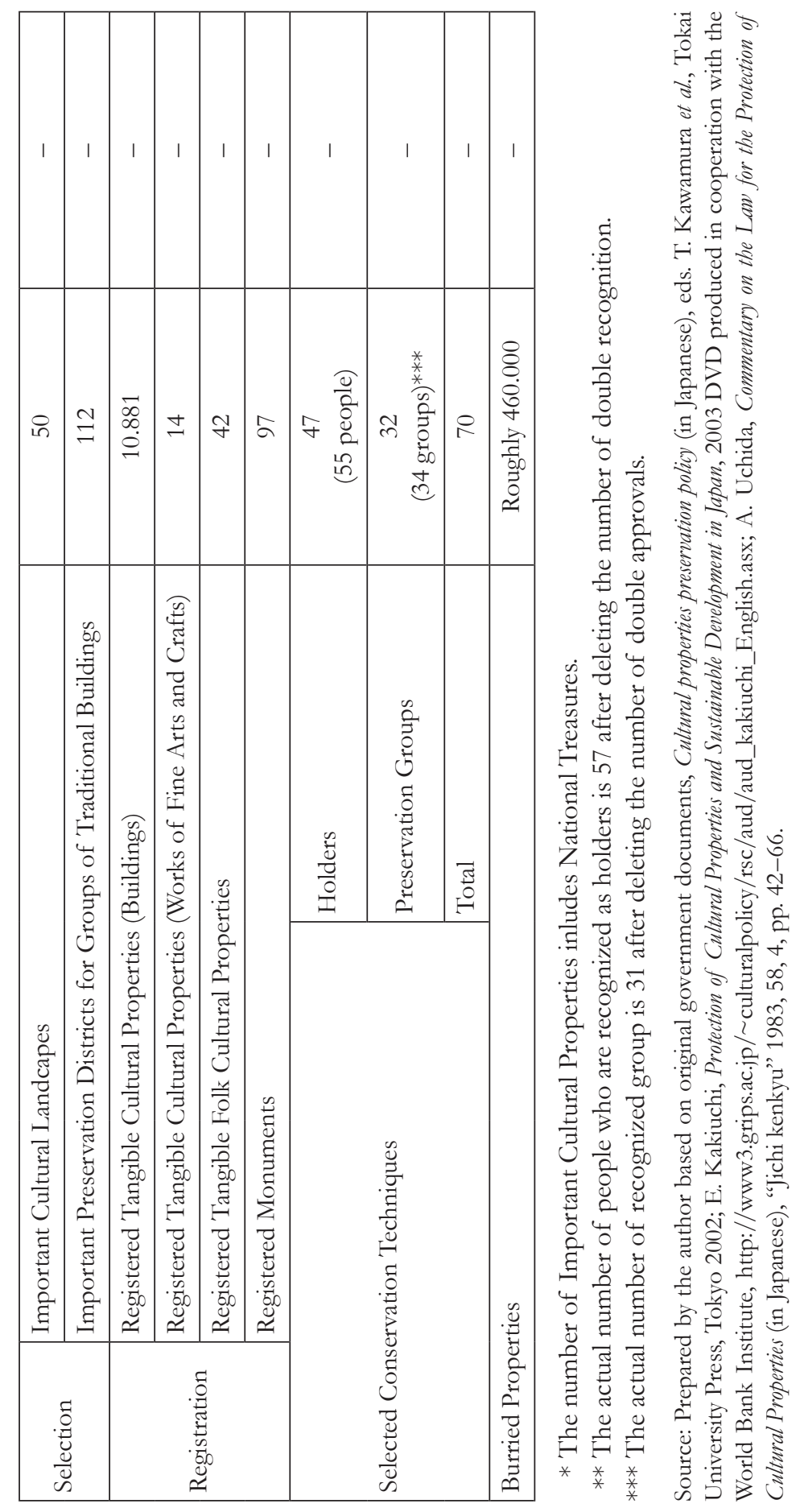


50 Important Cultural Landscape have been selected since the introduction of this category in 2004, including wetland, farm villages, rice terraces, and river basins. 112 Important Preservation Districts for Groups of Traditional Buildings have been selected since 1975 .

More than 10,000 Tangible Cultural Properties (Buildings) have been registered since 1996, and 14 Works of Fine Arts and Crafts, 42 Tangible Folk Cultural Properties, and 98 Monuments have been registered since 2004.

In addition, there are now 70 Selected Conservation Techniques, including 48 holders and 31 preservation groups. Roughly 460,000 ruins are known as Buried Cultural Properties, the excavation of which is restricted for protection.

\section{4) Current issues}

Heritage is a result of our predecessors work, which provided the foundations of social identity. It should be noted that heritage is not only to be protected but also to be utilized as an incubator for new cultural creation, as clearly stipulated in article 1 of the LPCP. The cultural properties protection system in Japan has been significantly expanded in recent years, with more diversified measure to accommodate life style and daily work in communities. However, much heritage has yet been lost.

In this section, we will discuss issues and problems regarding efficient implementation of the system, and in the following section social and economic changes influencing the system will be examined.

\section{a) Scarce resources}

The amount of public funds allocated to culture in Japan, including cultural properties protection, is very small. At the national level, the Agency for Cultural Affairs (the ACA) has prime responsibility for culture, and its budget has remained at the level of only $0.1 \%$ of the total general account of the national government for several decades. Looking at a breakdown, roughly $60 \%$ of the ACA budget is now allocated to heritage and the rest for arts support. Of the budget for heritage, roughly $40 \%$ of the ACA budget is allocated to heritage protection, and roughly $20 \%$ is allocated to maintenance and management of national museums and theaters of heritage protection ${ }^{4}$. Due to the limited resources in actual implementation, many classified cultural properties are waiting for the support stipulated by LPCP.

Other ministries such as the Ministry of Land, Infrastructure, Transport and Tourism, the Ministry of Agriculture, Forestry and Fisheries, the Ministry of In-

4 Agency for Cultural Affairs, 2016, Overview of the Budget for 2016 of the Agency for Cultural Affairs, http://inquiry.bunka.go.jp/seisaku/bunka_gyosei/yosan/pdf/h28_yosan.pdf (accessed: 19.12.2016). 
ternal Affairs and Communications, and others are also spending relatively large budgets related to culture. However, it should be noted that their focus is on their own policy areas such as urban planning, agriculture, and local revitalization, and not culture per se.

Furthermore, local systems vary from city to city, with spending fluctuating resources according to financial conditions. Shortly after the bubble economy burst in 1989, total annual spending on culture by local governments hit its highest level of more than 900 billion yen in 1993, but it had decreased with some fluctuation to around 414 billion yen until $2014^{5}$. Although the total annual spending on culture by local governments is still much larger than that of the ACA which is in charge of cultural promotion and protection within the national government, most local spending on culture is allocated to the construction and maintenance of cultural facilities and very little is allocated to cultural properties protection. Today there are 5,683 museums in Japan, most of which were established by local governments, and historical museums comprised more than half (3,299, Ministry of Education, Culture, Sports, Science and Technology, 2011) ${ }^{6}$. However, the budget for operation of historical museums and related activities has also been shrinking.

\section{b) Economic expectations}

Expectations for utilizing cultural properties for development have grown significantly. It should be noted that without an economically and socially viable community, cultural properties protection can not be sustained. At the same time, a community can benefit from culture in various ways. Therefore it is desirable to find ways to further link social and economic values with cultural values.

As a source of local development, more emphasis is being accorded to promoting cultural tourism and local traditional industries with a view to facilitating economic development and local sustainability. Traditional industries, however, have been deteriorating in Japan, due to mass production and distribution of daily necessities with less expensive prices, and changes of lifestyle. Despite the enactment of the Law for the Promotion of Traditional Craft Industries in 1974, traditional craft industries have been declining: the number of employees and sales dropped by around $75 \%$, the number of companies fell by $60 \%$ in these 30 years 7 .

5 Agency for Cultural Affairs, 2016, Cultural Administration of Local Governments 2014, http:// www.bunka.go.jp/tokei_hakusho_shuppan/tokeichosa/chiho_bunkagyosei/pdf/h26_gyosei. pdf (accessed: 19.12.2016).

6 Ministry of Education, Culture, Sports, Science and Technology, Social Education Survey interim report 2015, http://www.mext.go.jp/component/b_menu/other/__icsFiles/afieldfile/2016/10/28/1378656_03.pdf (accessed: 12.19.2016).

7 Association for the Promotion of Traditional Craft Industries, Current Status of Traditional Craft Industries, 2012, http://kougeihin.jp/association/state/ (accessed: 19.12.2016). 
On the other hand, tourism is attracting attention as a growing industry. According to the national estimate ${ }^{8}$, in 2013, travelers spent 22.5 trillion yen in Japan, which created roughly 4 million jobs (6.1\% of the total workforce). The estimate of direct and indirect economic impact was 46 trillion yen, which comprised $4.9 \%$ of GDP.

c) More comprehensive approach for protection

Despite the significant evolution of the cultural properties protection system, much remain to be protected: modern and industrial heritage, recorded materials, and Culture in Lifestyle such as tea ceremony and flower arrangement. In addition, many historic buildings of local importance as well as historic landscape are being lost. At the same time, it has become more difficult to find the necessary skills, skilled workers or even original materials necessary for repair of cultural properties. In other words, a more holistic approach to protection is needed, rather than categorical protection?

For social infrastructure development, a new system was recommended to protect historic landscapes. In 2008, the Act on the Maintenance and Improvement of Historic Landscape in Communities was introduced. This act aims to protect the historic landscape for both urban development and cultural promotion. The historic landscape can be defined as the landscape which has mixed components of historic buildings and daily operations of people, reflecting the local history and tradition. In the implementation, three sections of the national government (the Ministry of Land, Infrastructure, Transport and Tourism, The Ministry of Agriculture, Forestry and Fisheries, and the ACA) jointly supervise these efforts. The national government will set up a National Master Plan and then authorize local plans. With zoning, many projects aiming to improve the historic landscape will be supported.

This act provides a variety of support for projects, such as the repair, purchase, and renovation of historic buildings, improvement of old buildings, utilization of historic buildings through promoting traditional festivals, and manpower development. It can be said this is part of a more comprehensive approach to heritage protection which integrates tangible and intangible heritage protection projects.

In addition to implementing legal measures for heritage under LPCP and the act mentioned above, the ACA is also supporting measures for utilizing local heritage. One recent development is a project called "Japan Heritage" which was launched in 2014. This program supports efforts to use local heritage for regional revitalization and tourism promotion. Local governments are requested to propose a "story

8 Japan Tourism Agency, Economic Impact of tourism, http://www.mlit.go.jp/kankocho/siryou/ toukei/kouka.html (accessed: 19.12.2016).

9 Agency for Cultural Affairs, 2009, Comprehensive Understanding on Cultural Properties, Preservation and Utilization of Cultural Properties, http://www.bunka.go.jp/english/pdf/h21_chapter_06.pdf (accessed: 19.12.2016). 
telling" plan regarding their traditional culture; once the plan is approved, the ACA will provide budgetary and other necessary support.

5) Unclear prospects for the future: Heritage for development

In the $21^{\text {st }}$ century, facing aging and depopulation, and after the March 11, 2011 Tohoku earthquake, Japan is conducting ongoing socio-economic reforms due to the changing international environment and new domestic requirements. It is not easy to indicate the future direction of cultural properties protection under these unclear and changing conditions. However, in the long term, as mentioned above, some changes are apparent. Heritage will be more closely linked to social and economic development as an indispensable asset. Several possibilities can be pointed out.

\section{a) Devolution}

At the beginning of the protection system the national government designated cultural properties of national significance, while cultural properties of local importance are designated and protected by local governments. Gradually, local governments and residents of the community came to play more important roles in deciding what to be classified as national assets and how to protect them. As seen in Preservation District for Groups of Traditional Buildings and Cultural Landscape, the cultural properties protection system has evolved from a top down system to a more flexible bottom up system with consideration of local demands. This tendency can be seen not only in system under LPCP for the Protection of Cultural Properties, but also in other legal systems which have been introduced recently. This clearly indicates that cultural properties are more closely integrated with local daily life, and cultural properties of local importance will be integrated more into the overall protection system.

\section{b) Cooperation among various stakeholders}

It is primarily the responsibility of the owners of cultural properties to take protection measures. However, there is a strong consensus of the national population that cultural properties should be passed on to succeeding generations, and that they cannot be preserved solely by the efforts of owners and local residents. Most Japanese people are willing to pay a significant amount for heritage protection according to Contingent Valuation Method (CVM) studies ${ }^{10}$. At the same time, one

10 E. Kakiuchi, Sustainable cities with creativity: Promoting creative urban initiatives: Theory and practice in Japan [in:] Sustainable city and creativity: Promoting creative urban initiatives, eds. L.F. Girard, T. Baycan, P. Nijkamp, UK: Ashgate Publishing Limited 2012, pp. 413-440; Evaluating the heritage values (in Japanese), ed. E. Kakiuchi, Tokyo: Suiyosha Publishing Inc 2011; Y. Kodama, T. Tamazawa, 
of the most important values of cultural properties might be the bequest value: the value derived by people today from the expected enjoyment of heritage by future generations. It can be said that cultural properties are public goods for society as a whole, which warrants government support.

On the other hand, there are specific segments of the population who are more concerned than average about heritage values and who would be willing to pay a considerable amount, as the mean willingness to pay (which indicates the socially appropriate level of the resources to be allocated for heritage protection) is much larger than the median willingness to pay (which indicates politically acceptable level for resource allocation). In other words, public support by government would be justifiable to a degree, but falls below the necessary level for protection of the cultural value of heritage. Thus, in addition to government support, it is necessary to involve all of the other beneficiaries of the values of cultural properties, not only visitors and tourists who enjoy the cultural value of heritage, but also tourism-related companies, NPOs, volunteers and others who are concerned. In order to further increase the momentum of these efforts, government support and endorsement should be provided together with private initiatives. For this, appropriate information sharing is essential.

c) Integration of cultural properties protection with development

As cultural properties have become more integrated into local development, various stakeholders with different interests have emerged and become involved in the protection of cultural properties. The cultural properties protection system needs closer cooperation with other policy areas such as tourism, industries, local development, as well as more effective coordination among governments and private entities.

It is crucial to increase non-governmental involvement in order to obtain the financial resources necessary to maintain cultural values. In order to provide satisfaction constantly to visitors, it is indispensable to maintain the cultural values as the core elements of attractiveness.

Considering the scarce resources from government in actual implementation, it is necessary to mobilize all possible resources for cultural properties protection. Tourists are especially important supporters, and various measures to realize their potential support for cultural properties protection, such as establishing funds for donations, and introducing membership and ownership, entry fees, and hotel taxes, are needed. Finally, tourism related businesses should recognize the necessity of participating in heritage protection in various ways.

K. Ujiie, E. Kakiuchi, T. Okuyama, An economic analysis of cultural capital's value: A study of Miyajiama, Hiroshima (in Japanese), "Journal of the City Planning Institute of Japan" 2007, no. 42(1), pp. 93-99; E. Kakiuchi, The possible model for culture-based tourism development in Japan: Implication of CVM survey of the World Heritage of Gokayama, Toyama Prefecture, Japan [in:] UNWTO, Tourism and community development: Asian practices, Madrid 2008, pp. 163-183. 


\section{STRESZCZENIE}

\section{SYSTEM OCHRONY DZIEDZICTWA KULTUROWEGO W JAPONII. AKTUALNE PROBLEMY I PERSPEKTYWY NA PRZYSZLOŚĆ}

W artykule na podstawie analizy rozwoju systemu ochrony dziedzictwa w Japonii przedstawiono, w jaki sposób wzrastało jego społeczne znaczenie. Ochrona dziedzictwa jest urzeczywistniana od ponad 150 lat, głównie przez rząd krajowy. Epokowe wydarzenia, takie jak modernizacja okresu restauracji Meiji od 1868 r. i demokratyzacja pod koniec II wojny światowej w 1945 r., znacząco wpłynęły zarówno na znaczenie dziedzictwa, które ma być chronione, jak i system ochrony. Ocalenie własności upadającej arystokracji i świątyń było pierwotnym celem pod koniec XIX w., a bezpośrednio przed II wojną światową na znaczeniu zyskała motywacja nacjonalistyczna. Po II wojnie światowej dziedzictwo uznano za dobro narodowe, ale przez dłuższy czas pozostawało stosunkowo niewielkim elementem życia społeczeństwa. Jednak w ostatnim czasie wartość dziedzictwa zaczyna być dostrzegana, a środki ochrony stają się zróżnicowane, ponieważ Japonia dojrzała pod względem społecznym i gospodarczym. Obecnie dziedzictwo jest zintegrowane i ściśle powiązane z rozwojem społeczności lokalnych, a jego ochrona jest realizowana nie tylko przez rząd, ale także przez różne inne podmioty. 